\title{
ポリ(2,6-ジメチル-1,4-フェニレン)エーテルとポリェチレンのブレンド系の 射出成形品中における相反転特殊傾斜構造の形成
}

\author{
佐野博成 $* 1$ 倉沢 義博*2・西田 耕治*2
}

（受付 1996 年 12 月 3 日・審査終了 1997 年 1 月 29 日）

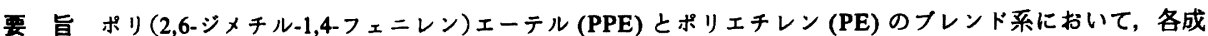
分のレオロジー特性ならびに構成比による成形品の厚み方向におけるモルフォロジー变化を検討した. その結果, ある配合系において, その射出成形品の厚み方向で相反転が 1 回ないしは 2 回起きる特殊な傾斜粠造の形成が観察 された.この形成機構は, 組成の変動ではなく, 射出成形充塤時のずり速度と樹脂温度に支配される両成分の溶融 粘度比が成形品の厚み方向で変化していることで説明される. 特殊傾斜構造の形成により発現する物性は, PPE マ トリックスまたはPEマトリックスの平均的値ではなく，両相の相乗的な物性を有する，従来にない優れた材料特 性を示すことが明らかになった。
\end{abstract}

\section{1. 緒言}

各種樹脂の高性能化には, アロイ,ブレンド, コンポ ジットのいわゆる ABC の技術が欠かせない，単一の材 料では得られない高度の特性を異質な材料の組み合わせ によって発現させる狙いである. エンジニアリングプラ スチックもその例に漏れない.

中です，不均一ブレンド材料では多相構造を制御する 技術により高度な複合特性を発現させることが図られて きた. 押出機を用いた溶融混練による構造制御の研究は これまでにも数多く行われている1),2) が, 成形加工まで 考虑した研究例は少なく, 層状の分散構造制御), 4) がい くつか見られる程度である. 成形加工による構造形成を 考えるには, 成形過程中における溶融粘度の変化やずり 速度分布などを詳細に検討する必要がある.

そこで我々は, 非晶性樹脂としてポリ (2,6-ジメチル1,4-フェニレン) エーテル (PPE), 結晶性樹脂としてポ リエチレン (PE) を用いたブレンド系において, 各構成 成分のレオロジー特性, 構成比, および成形条件を考虑 することにより, 射出成形品の厚み方向におけるモル フォロジーが制御された, 新たな傾斜構造の形成が可能 であることが明らかになったので報告する.

\section{2 実験方法}

\section{1 試料}

本検討に用いた各成分の種類と特性値を Table 1 に示

*1 三菱化学(株)物性分析第 1 研究室（５10 四日市市東邦町 1)

* 三菱エンジニアリングプラスチック（株）（②54 平塚市東 八幡 5-6-2)
す. ポリ (2,6-ジメチル-1,4-フェニレン)エーテル (PPE) は三菱ガス化学(株)製，ポリエチレンは三菱化学(株)製 を用いた. PPEの粘度調節のため三菱化学(株)製のポ リスレン (PS) をPPE と併用して用いた。 なお，すべて の試料について, シェル化学社製のスチレンーブタジェ ンースチレンブロック共重合体の水素添加物 (SEBS) を 相溶化剂として, PPE, PS, および PEの合計 100 重量 部に対して 10 部添加し，また，無機フィラーとして平 均粒子径 $0.3 \mu \mathrm{m}$ の重質炭酸カルシウムを 6 重量部添加 した.

ブレンドは Table 2 に示す所定の配合比で混合後, （株）日本製鋼所製 $44 \mathrm{~mm}$ 異方向回転二軸押出機を用い て, $230^{\circ} \mathrm{C}$ のシリンターー温度, $250 \mathrm{rpm}$ のスクリュウ回 転数の設定のもと, 溶融混練することによりペレットを 作成した。

\section{2 射出成形}

溶融混練した各ブレンド試料は，（株)日本製鋼所製射 出成形機（型締め力 100 ton）を用いて, 成形温度 $280^{\circ} \mathrm{C}$, 金型温度 $60^{\circ} \mathrm{C}$, 充媜時間 2.5 秒の条件で試験片 （サイズは $120 \mathrm{~mm} \times 80 \mathrm{~mm}, 2 \mathrm{~mm}$ 厚み）を成形した.

\section{3 測定}

2.3.1 透過型電子顯微鏡 (TEM) 寉察 TEM を用い て成形品厚み方向の形態（ディプスプロファイル）を射 出流動方向に平行な方向 (End) から観察した. 試料は 四酸化ルテニウムでブロック染色し，ダイヤモンドナイ フを装着したウルトラミクロトームで薄切り後, 加速電 圧 $100 \mathrm{kV}$ の日本電子(株)製 TEM (JEM100CX) を用い て観察した。

2.3.2 剪断溶融粘度の測定 ブレンドした各成分の 剪断溶融粘度をキャピラリー型レオメーター（東洋精機 
PPE と PE のブレンド系の射出成形品中における相反転特殊傾斜構造の形成

Table 1. Characteristics of materials used in this work

\begin{tabular}{ccccc}
\hline \hline & Component & MFR & $\left.M_{w}{ }^{b}\right)$ & \multicolumn{1}{c}{ Remarks } \\
\hline \multirow{2}{*}{ PPE } & PPE-1 & & 51000 & $T_{\mathrm{g}}, 210^{\circ} \mathrm{C}$ \\
\cline { 2 - 5 } & PPE-2 & & 69000 & $T_{\mathrm{g}}, 213^{\circ} \mathrm{C}$ \\
\hline PS $)$ & & $7.5\left(200^{\circ} \mathrm{C}, 5 \mathrm{~kg}\right)$ & 215000 & $T_{\mathrm{g}}, 100^{\circ} \mathrm{C}$ \\
\hline & PE-1 & $0.02\left(190^{\circ} \mathrm{C}, 2.16 \mathrm{~kg}\right)$ & 201000 & Density, $0.947 \mathrm{~g} / \mathrm{cm}^{3}$ \\
\cline { 2 - 5 } PE & PE-2 & $0.6\left(190^{\circ} \mathrm{C}, 2.16 \mathrm{~kg}\right)$ & 142000 & Density, $0.952 \mathrm{~g} / \mathrm{cm}^{3}$ \\
\cline { 2 - 5 } & PE-3 & $1.5\left(190^{\circ} \mathrm{C}, 2.16 \mathrm{~kg}\right)$ & 100000 & Density, $0.952 \mathrm{~g} / \mathrm{cm}^{3}$ \\
\hline & PE-4 & $90\left(190^{\circ} \mathrm{C}, 2.16 \mathrm{~kg}\right)$ & 33500 & Density, $0.931 \mathrm{~g} / \mathrm{cm}^{3}$ \\
\hline SEBS & & & 80000 & Styrene cont., $29 \mathrm{wt} \%$ \\
\hline
\end{tabular}

a) Melt flow rate $(\mathrm{g} / 10 \mathrm{~min})$. b) Weight average molecular weight by GPC. c) PS, polystyrene. d) SEBS, styreneethylene butylene-styrene.

Table 2. Blend systems used in this work

\begin{tabular}{ccccc}
\hline \hline Sample & PPE & PS & PE & $\begin{array}{c}\text { PPE(PS)/PE } \\
\text { (wt\%) }\end{array}$ \\
\hline 1 & PPE-1 (48) & $(32)$ & PE-1 (20) & $80 / 20$ \\
2 & PPE-1 (42) & $(28)$ & PE-1 (30) & $70 / 30$ \\
3 & PPE-1 (36) & $(24)$ & PE-1 (40) & $60 / 40$ \\
4 & PPE-1 (30) & $(20)$ & PE-1 (50) & $50 / 50$ \\
5 & PPE-1 (16) & $(64)$ & PE-2 (20) & $80 / 20$ \\
6 & PPE-1 (48) & $(32)$ & PE-3 (20) & $80 / 20$ \\
7 & PPE-2 (48) & $(32)$ & PE-4 (20) & $80 / 20$ \\
\hline
\end{tabular}

製作所 (株) 製キャピログラフ 1-B) を用いて, 温度 $160^{\circ} \mathrm{C}$ から $320^{\circ} \mathrm{C}$ まで変化させて罗断速度の依存性を測 定した.

2.3.3 DSC の測定 射出成形品表面から一定間隔で 切片を作成し，セイコー電子(株) 製 DSCを用いて, $320^{\circ} \mathrm{C}$ で $10 \mathrm{~min}$ 溶融させた後 $5^{\circ} \mathrm{C} / \mathrm{min}$ の速度で降温し たときの熱量を測定した.

\section{3 蛣果と考察}

3.1 組成比とモルフォロジー

射出成形品のモルフォロジー（ディプスプロファイ ル）に及ぼす PPE (+PS) と PE の組成比の影整を試料 1〜4を用いて検討した。

試料 1 の射出成形品につき, 表面からの距離を変えて 連続的に観察した. そのモルフォロジーの一例を Fig. 1 に示す. 表面からの距離 (mm) は, 0.1 (a), 0.2 (b), 0.4 (c), 0.7 (d), および成形品中央部の 1.0 (e) である. 写 真で灰色に一様に染色されている相がPPE と PS から 成る相 (PPE + PS) である. 表面付近ではモルフォロ ジーに異方性は存在するものの, 成形品厚み方向のすべ ての部位において PPE+PS 相がマトリックスを形成
し，PE 相がドメインを形成していることがわかる．同 様な観察を試料 2 について行った結果を Fig. 2 に示す. 表面からの距離は Fig. 1 と同じである.PE 成分量が試 料 1 の $20 \mathrm{wt} \%$ から $30 \mathrm{wt} \%$ まで大きくなることによ り, 試料 1 とは異なった特殊なモルフォロジーが形成さ れている. すなわち, 表面から $0.1 \mathrm{~mm}$ (a) までの領域 では, 試料 1 と同様に PPE+PS がマトリックスを形成 しているが, それより内部の (c) では, PPE+PS 相が ドメイン, PE 相がマトリックスを形成し, 表面層部分 とは海島の構成成分が逆であり, 相反転現象が生じてい ることが分かる. さらに, 内部の (e) では, 再度 PPE +PS 相がマトリックスを形成している. したがって, 成形品の表首から中央部までの領域において, PPE+ PS 相とPE 相が二度にわたって相反転が生じる従来に ない構造（相反転傾斜構造と称する）が形成し，その相 反転が起こる境界領域 (b), (d) では両相（PPE+PS 相 と PE 相）の共連続構造が現れている. 試料 3 の形態 も 試料 2 と同様に, 二度の相反転が成形品厚み方向で生じ る傾斜構造が観察された. PPE+PS 成分に対する PE 成分量が 50/50の試料 4 では, Fig. 3 に示すように, $0.2 \mathrm{~mm}$ (b) までの表面部では PPE + PS 成分がマトリッ 


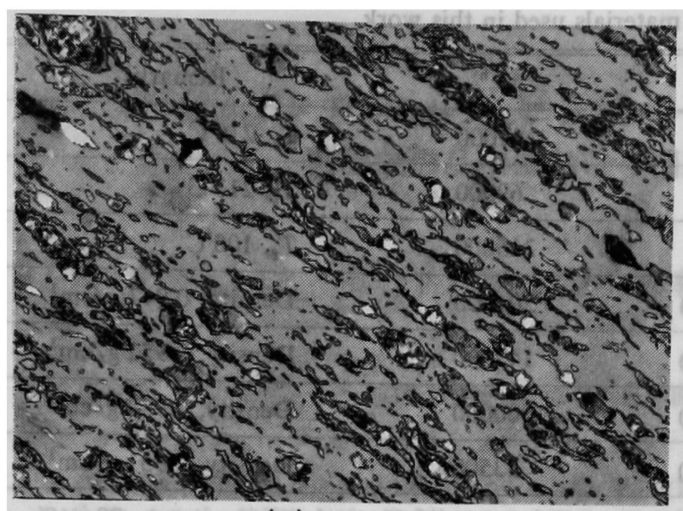

(a)

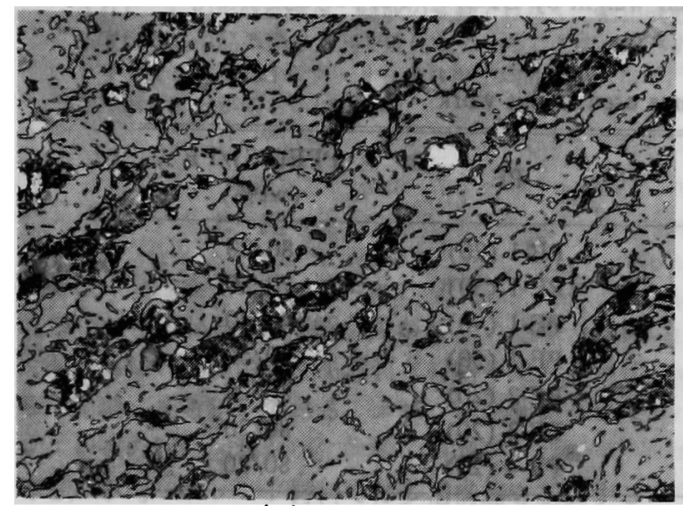

(c)

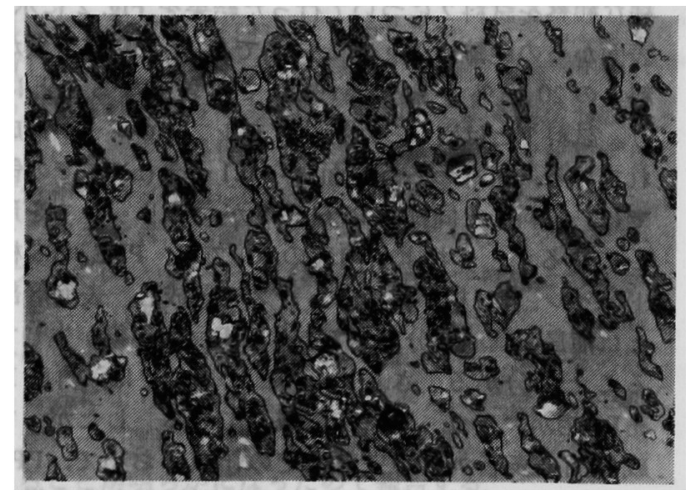

(e)

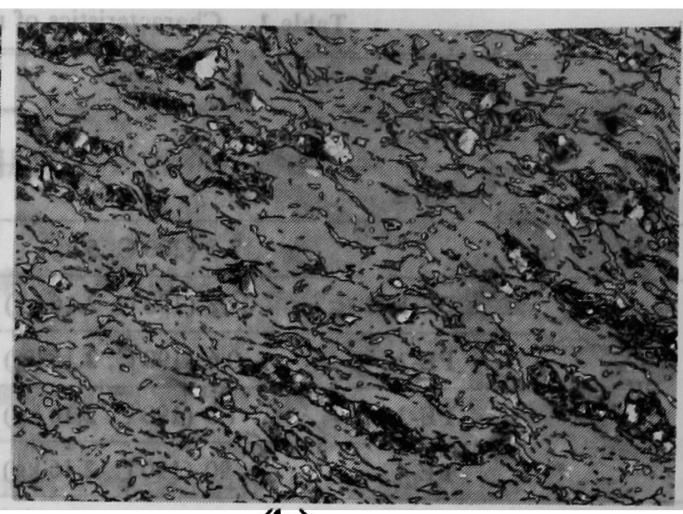

(b)

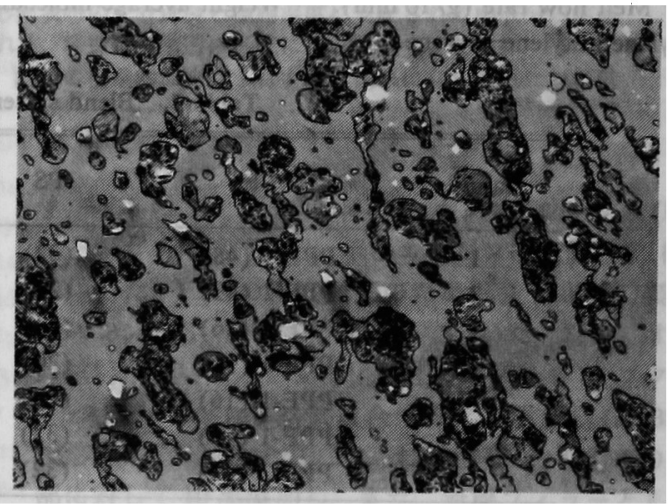

(d)

\section{$2 \mu \mathrm{m}$}

Fig. 1. Transmission electron micrographs of sample 1 at various positions below the surface of the injection molded sheet. Depth from surface, (a) $0.1 \mathrm{~mm}$, (b) $0.2 \mathrm{~mm}$, (c) $0.4 \mathrm{~mm}$, (d) $0.7 \mathrm{~mm}$, and (e) $1.0 \mathrm{~mm}$.

クスとなっているが, $0.4 \mathrm{~mm}$ (c) 内部から中央部 (e) まで PPE+PS 成分がドメインを形成し，相反転が一度 起きているモルフォロジーであった.

PPE + PS に対する PE の組成比をさらに高めていく
と, PPE+PSが厚み方向の全域にわたってドメインを 形成していることが確認された.

二成分ブレンド系では, マイナーな成分がドメインを 形成し，その粒径が組成比に依存することは一般的に良 
PPE とPE のブレンド系の射出成形品中における相反転特殊傾斜構造の形成

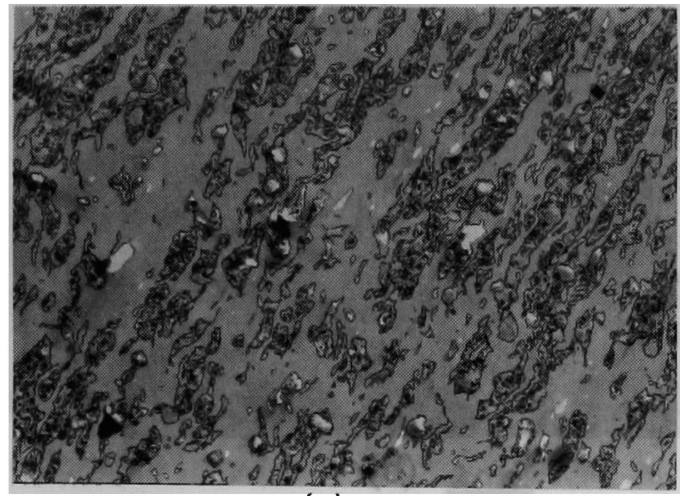

(a)

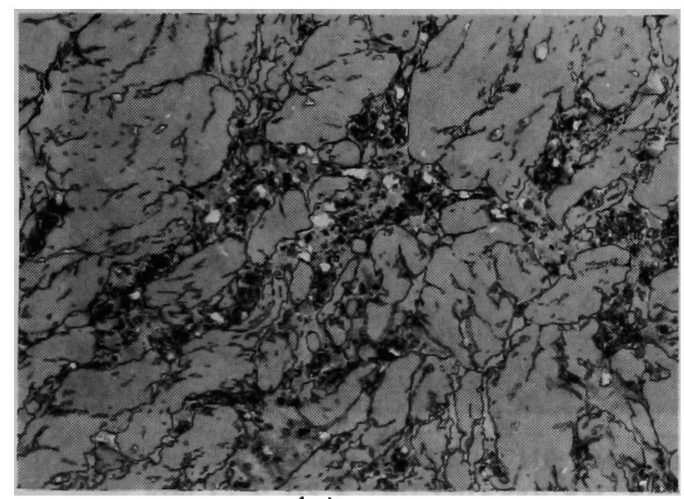

(c)

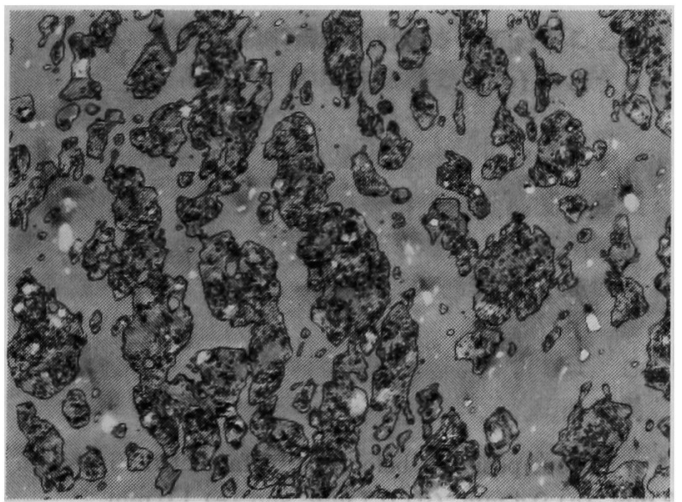

(e)

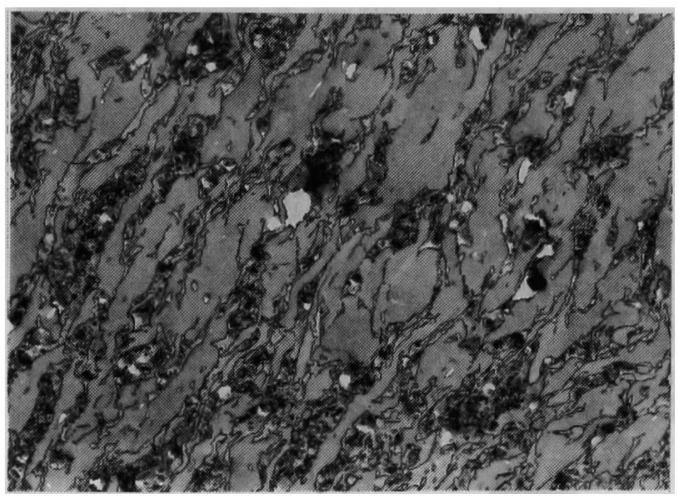

(b)

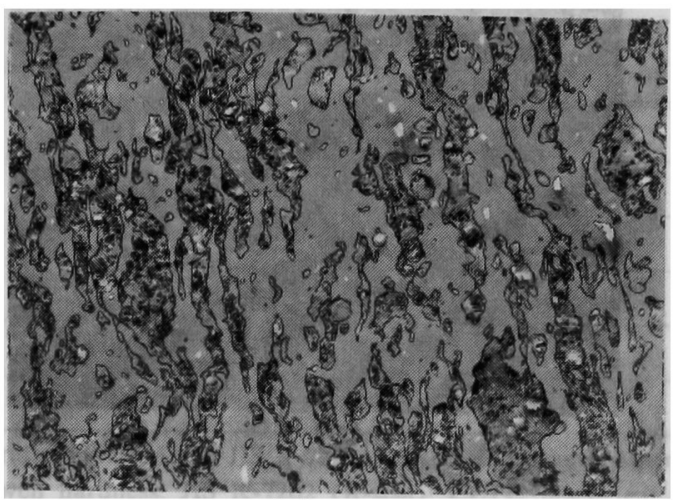

(d)

\section{$2 \mu \mathrm{m}$}

Fig. 2. Transmission electron micrographs of sample 2 at various positions below the surface of the injection molded sheet. Depth from surface, (a) $0.1 \mathrm{~mm}$, (b) $0.2 \mathrm{~mm}$, (c) $0.4 \mathrm{~mm}$, (d) $0.7 \mathrm{~mm}$, and (e) $1.0 \mathrm{~mm}$.

く知られている5゙ が，上記のような成形品の厚み方向に おける相反転現象は初めてのことである.

3.2 溶融粘度とモルフォロジー

PPE + PS 成分と PE 成分の組成比を 80/20 wt 比に固
定し, 各成分の分子量 (Table 1) を変化させた試料 5〜 7 を用いて，その成形品のモルフォロジーを観察した。 試料 5 は, PPE へのPS の添加量を增大させて低粘度 化し，逆に，PE成分は高分子量物を用いたブレンドで 


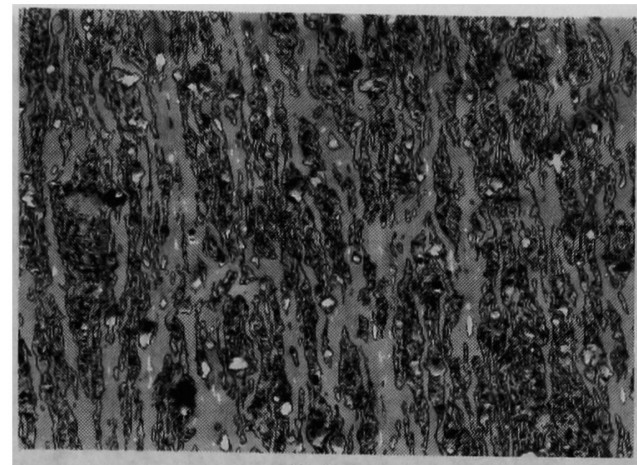

(a)

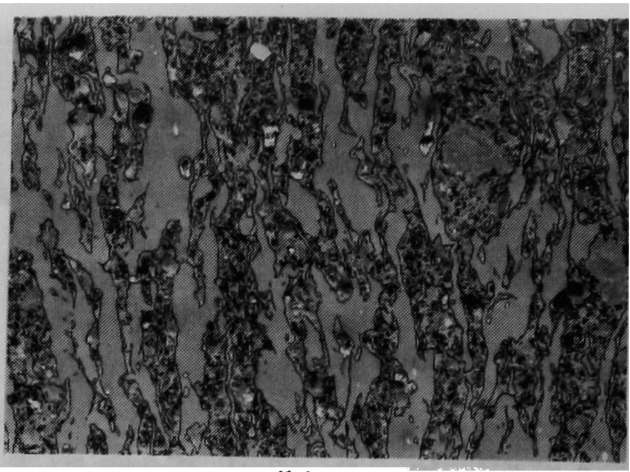

(b)

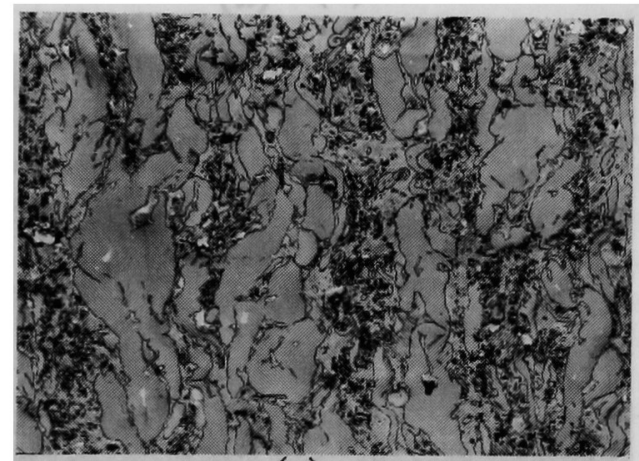

(c)

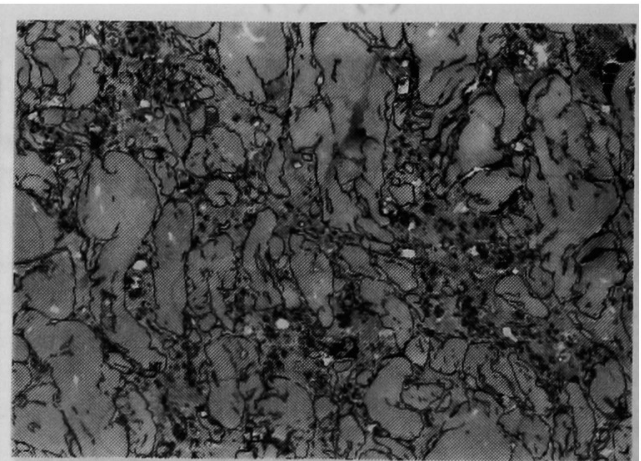

(d)

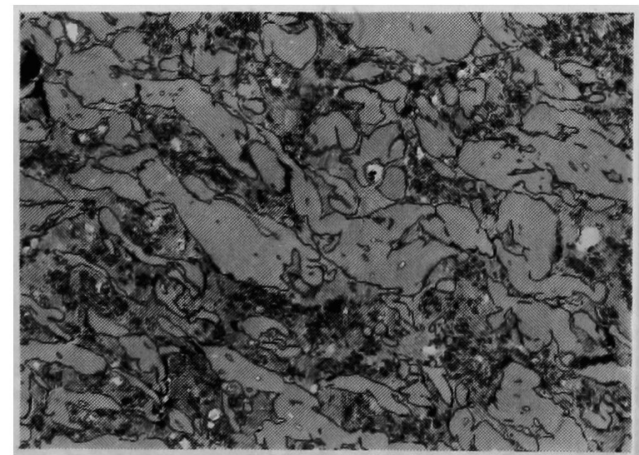

(e)

\section{$2 \mu \mathrm{m}$}

Fig. 3. Transmission electron micrographs of sample 4 at various positions below the surface of the injection molded sheet. Depth from surface, (a) $0.1 \mathrm{~mm}$, (b) $0.2 \mathrm{~mm}$, (c) $0.4 \mathrm{~mm}$, (d) $0.7 \mathrm{~mm}$, and (e) $1.0 \mathrm{~mm}$.

ある. そのモルフォロジーのディプスプロファイルを観 察した結果, 成形品厚み方向すべての領域で Fig. 4 に 示すような PPE + PS 成分がマトリックス, PE成分が ドメインを形成していることが明らかになった。逆に, 試料 7 は, 高分子量の PPE-2 と低分子量の PE-4 のブレ ンドであり, そのモルフォロジーは Fig. 5 に示したよ うに PPE＋PS 成分がドメイン, PE成分がマトリック
スである海島モルフォロジーが成形品全域において観察 された.

一方, 試料 6 は, PPE + PS 成分と PE 成分の粘度比 が, 試料 5 と 6 の間に位置するブレンドである. そのモ ルフォロジーのディプスプロファイルを Fig. 6 に示す. 表首部分 (a)で PPE + PS 成分がマトリックス, (c) 部 でドメイン, さらに内部の (d)や (e) 部で再度マトリッ 


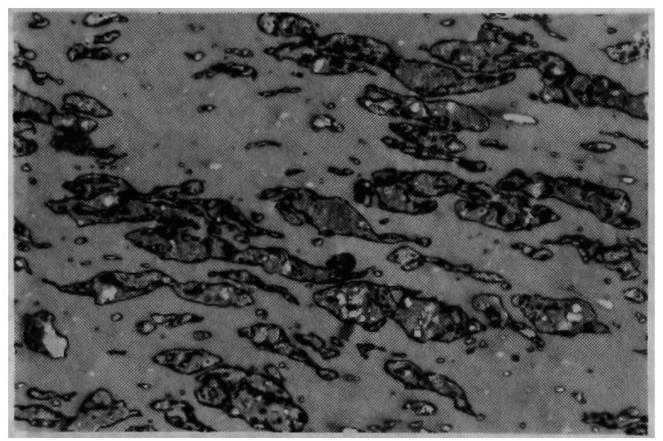

$2 \mu \mathrm{m}$

Fig. 4. Transmission electron micrograph of sample 5 at the position $0.4 \mathrm{~mm}$ below the surface.

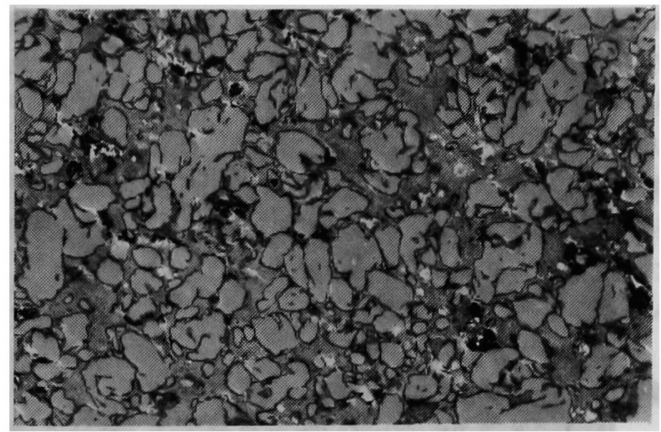

$\underline{2 \mu \mathrm{m}}$

Fig. 5. Transmission electron micrograph of sample 7 at the position $0.4 \mathrm{~mm}$ below the surface.

Table 3. Mechanical and thermal properties of blends ${ }^{a)}$

\begin{tabular}{cccccc}
\hline \hline Sample & IIS & FM & DTUL & RH & CLTE \\
\hline 5 & 105 & 1960 & 104 & 95.9 & 7.0 \\
\hline 6 & 150 & 2000 & 137 & 96.7 & 7.1 \\
\hline 7 & 59 & 1170 & 115 & 72.0 & 9.5 \\
\hline PPE/PE & 115 & 1980 & 179 & 95.2 & 7.3 \\
\hline PS/PE & 42 & 1900 & 93 & 92.0 & 7.2 \\
\hline
\end{tabular}

IIS, izod impact strength (J/m): JIS K-7110; FM, flexural moduli (MPa): JIS K-7203; DTUL, deflection temperature under load $\left({ }^{\circ} \mathrm{C}\right)$ : JIS K-7207 (10.4 kg); RH, Rockwell hardness: JIS K-7202 (R-scal); CLTE, coefficient of linear thermal expansion $\left(\times 10^{-5} /{ }^{\circ} \mathrm{C}\right)$ : JIS K-6714.

クスを形成し，相反転傾斜構造が形成されていることが 明らかになった。 なお，その境界領域では (b) のような 共連続構造が観察された.

以上の 3.1 およひ 3.2 で示したモルフォロジーのディ プスプロファイルを, PPE+PS成分の量と粘度で整理 して模式的に Fig. 7 に示した. ある特定の組成領域な らびに粘度領域で相反転による特殊な傾斜構造が生成し ていることがわかる.

二成分の溶融粘度比と分散粒径の関係については, こ れまでにもいろいろ研究されている6).7)が, 上記の特異 的な相反転現象は見つかっていない.したがって, 新た な観点からの解釈が必要である.

\section{3 特殊傾斜構造形成機構}

3.3.1 成形品中における組成分布 DSC 測定による 結晶化熱量から成形品各部位の PE 成分量を求めた。 二 度の相反転が起きていた試料 6 の成形品表面に平行にミ クロトームを用いて, $0.1 \mathrm{~mm}$ 間隔で $20 \mu \mathrm{m}$ 厚みの切片 を切り出し，DSC 測定から結晶化熱量を測定した。一 方, ブレンドに用いた PE-1 を同条件で測定を行い，そ れらの熱量比から各層における PE の存在量を計算し
た. Fig. 8 に示した結果から明らかなように, 組成変化 は $\pm 2 \%$ 程度の範囲内にあり，Fig. 2 に示した相反転 が起きている領域での顕著な組成変化は認められなかっ た. したがって, 相反転が生じる現象は, 成形品中の局 部における組成変化とは関係ないことがわかる.

3.3.2 構成成分の溶融粘度 非相溶ブレンド系の溶 融体は, ずり流動場では一般に低粘度成分が高粘度成分 を包み込む，つまりェントロピーの増大が最小になるよ うに形状が変化して流動する8), 9ことが知られている. また, 高分子の流動では, 非ニュートン性が現れ溶融粘 度はずり速度に依存する.したがって，ある流動場に置 かれたブレンド系の海島構造を左右する因子としては, そのときの温度におけるずり速度により決定される各成 分の溶融粘度が重要であると考えられる.

そこで, PPE, PS, PPE+PS，およびPEの溶融粘度 のずり速度依存性を温度を変えて測定した．本検討に用 いた各成分の $280^{\circ} \mathrm{C}$ (a), $310^{\circ} \mathrm{C}$ (b) における溶融粘度の ずり速度依存性を Fig. 9 に示す. PPE (+PS) 成分と PE 成分では溶融粘度のずり速度依存性が異なり, PE 成分 のずり速度依存性が大きいことがわかる. 


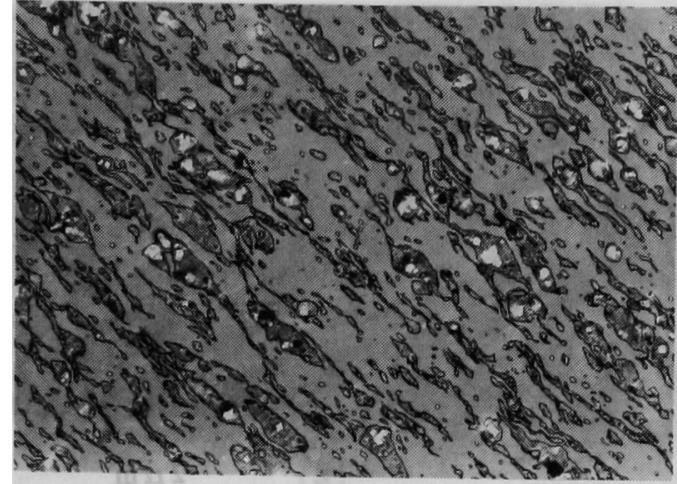

(a)

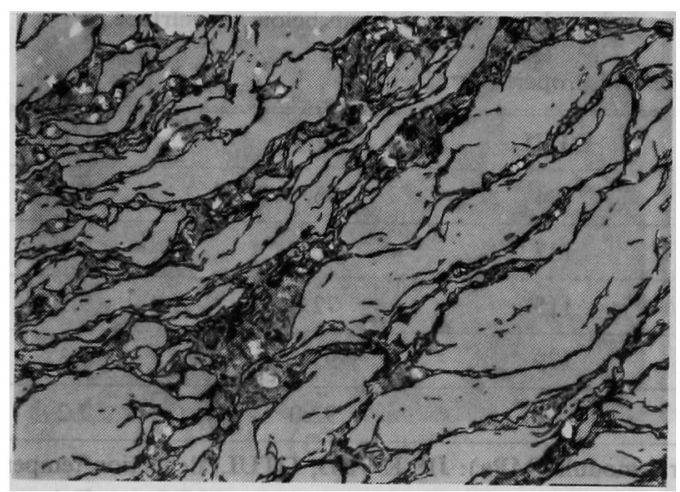

(c)

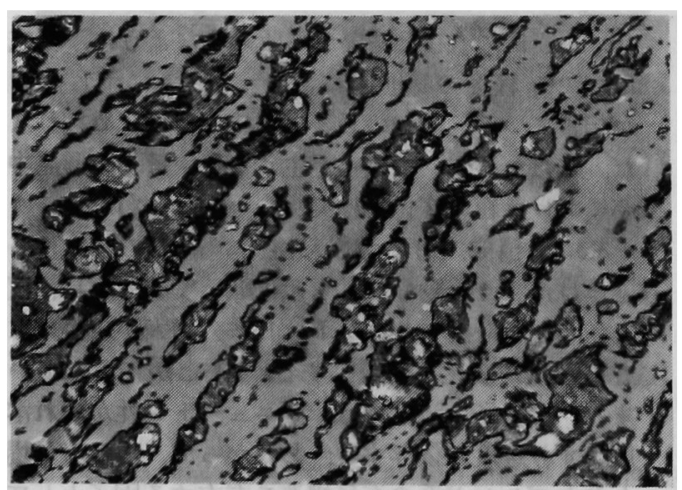

(e)

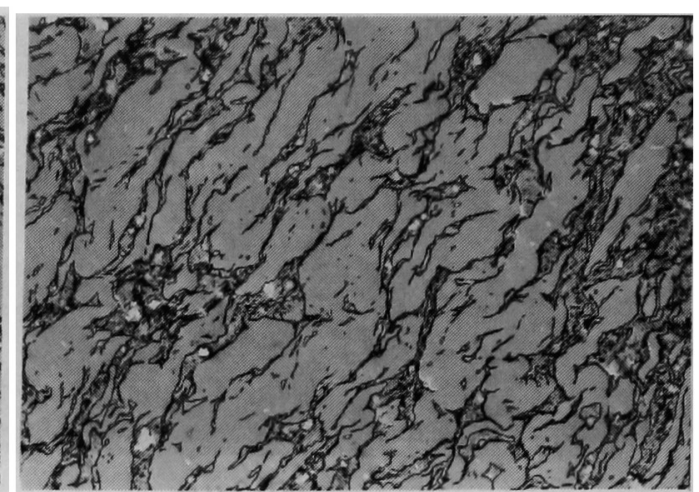

(b)

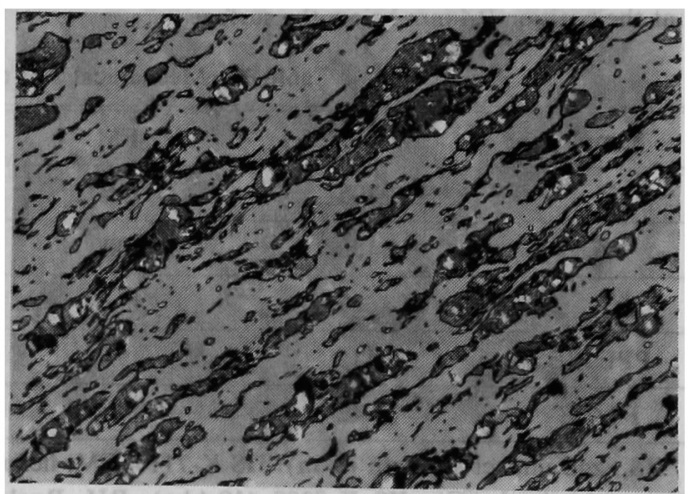

(d)

\section{$2 \mu \mathrm{m}$}

Fig. 6. Transmission electron micrographs of sample 6 at various positions below the surface of the injection molded sheet. Depth from surface, (a) $0.1 \mathrm{~mm}$, (b) $0.2 \mathrm{~mm}$, (c) $0.4 \mathrm{~mm}$, (d) $0.7 \mathrm{~mm}$, and (e) $1.0 \mathrm{~mm}$.

また，両成分では同一ずり速度下における溶融粘度の 温度依存性にも違いがあり,ずり速度が $120(1 / \mathrm{s})$ の時 の溶融粘度の温度依存性を Fig. 10 に示す. PPE + PS 成 分の溶融粘度の温度依存性は, PE 成分のそれに比べて
非常に大きいことがわかる.

3.3.3 溶融粘度比と海島構造 海島構造の形成に及 ぼす PPE +PS 成分と PE 成分の溶融粘度比ならびに組 成比の影響をモデル実験により検討した，組成の異なる 
PPE と PE のブレンド系の射出成形品中における相反転特殊傾斜構造の形成

試料 1〜4を用いて, キャピログラフにより $300^{\circ} \mathrm{C}$ と $250^{\circ} \mathrm{C}$ の温度でずり速度を $6 \sim 6000(1 / \mathrm{s})$ まで変化させ て押し出し, 急冷して得たストランドのモルフォロジー を観察して, 海島を形成している成分種の判定を行っ た.

例えば，Fig. 11 は試料 4 のストランドについて観察 した結果であり，ずり速度 (1/s) は，(a): 12.6, (b): 6000, (c): 600 である. 粘度のずり速度依存性から求め た粘度比 $\eta(\mathrm{PPE}+\mathrm{PS}) / \eta \mathrm{PE}$ は，(a): 0.8，(b): 3.0，(c): 1.1 である. この粘度比が 1 より小さい領域では PE 相 がドメイン (a), 1 より大きい領域では PPE 相がドメイ ンを形成したモルフォロジー(b) を示し, 粘度比が 1 前 後で共連続構造 (c) が観察される.

Fig. 12 はそれらの結果を組成比と粘度比で整理した あのである. 綎軸の粘度比 $\eta(\mathrm{PPE}+\mathrm{PS}) / \eta \mathrm{PE}$ は先に測

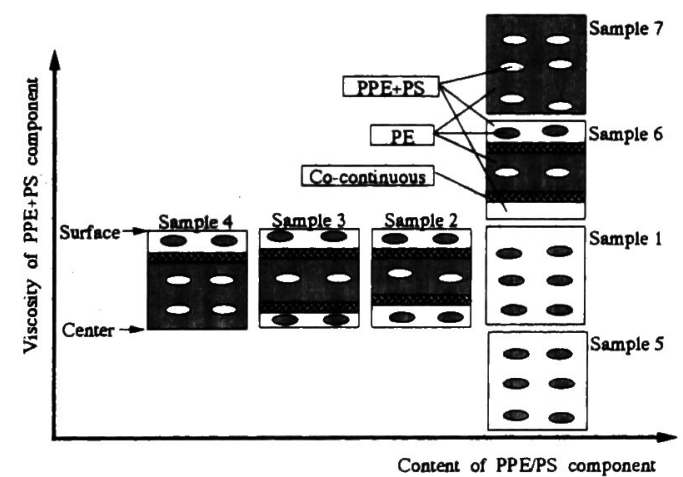

Fig. 7. Schematic representations of the change of phase morphology as a function of composition and shear viscosity.

(a)

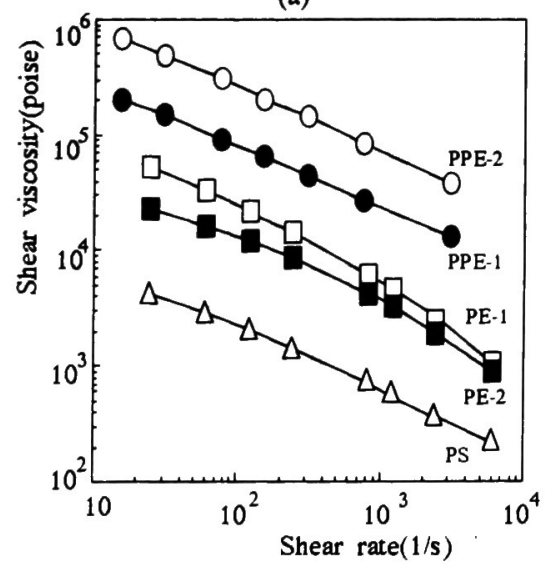

定した溶融粘度のずり速度依存性と温度依存性から求め た値である. 図中の四角印は両相が共連続構造を示して いる領域であり, その粘度比を臨界粘度比と定義する と, その臨界粘度比より $\eta(\mathrm{PPE}+\mathrm{PS}) / \eta \mathrm{PE}$ 值が大きい 領域では PPE + PS 成分がドメインであり, 逆に臨界粘 度比より小さい領域では PE成分がドメインを形成する ことになる.したがって, Fig. 12 により, 組成比とブ レンドされている各成分の粘度比から，その海島モル フォロジーの成分を特定することができる.

3.3.4 射出成形品中の海島構造反転機構 実際の射

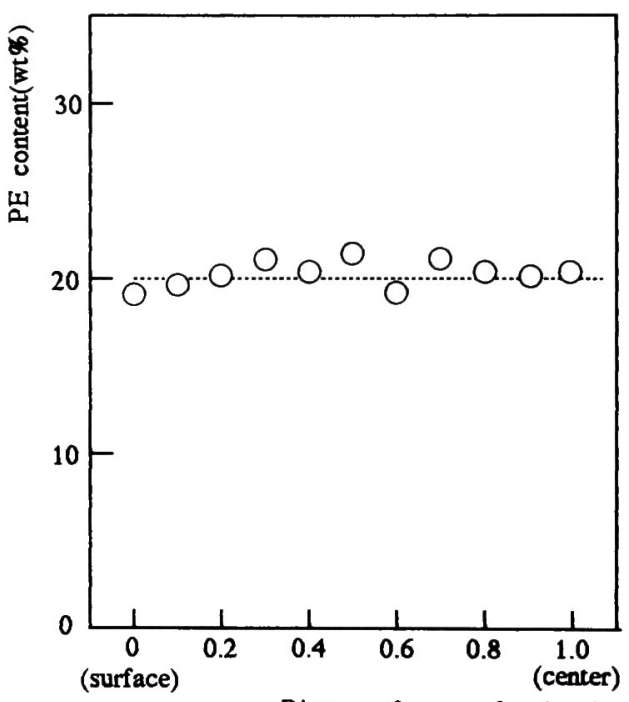

Distance from surface(mm)

Fig. 8. Relationship between PE content and distance from surface of injection molded sheet.

(b)

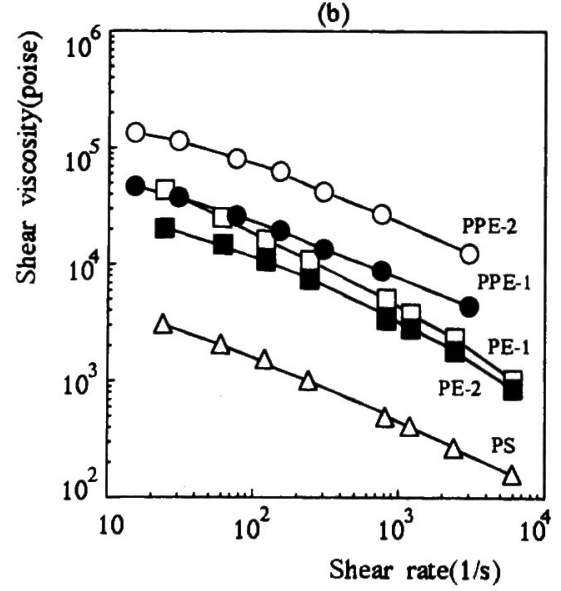

Fig. 9. Shear rate dependence of shear viscosity of PPE-1, PPE-2, PE-1, PE-2, and PS component at $280^{\circ} \mathrm{C}$ (a) and $310^{\circ} \mathrm{C}$ (b). 
佐野・倉沢・西田

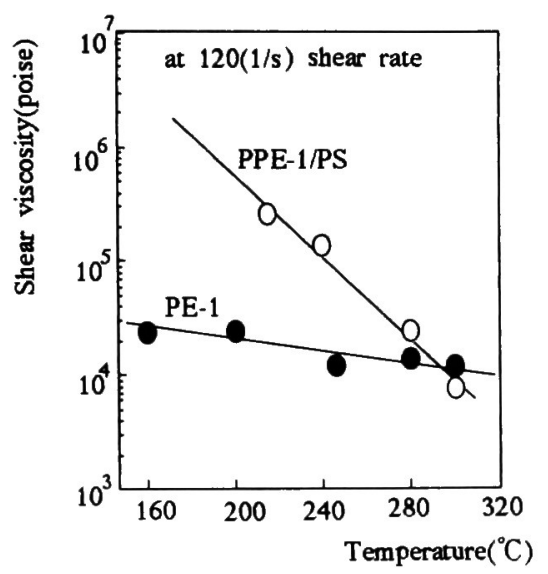

Fig. 10. Temperature dependence of shear viscosity of PPE-1/PS (60/40 wt\%), and PE-1.

(a)

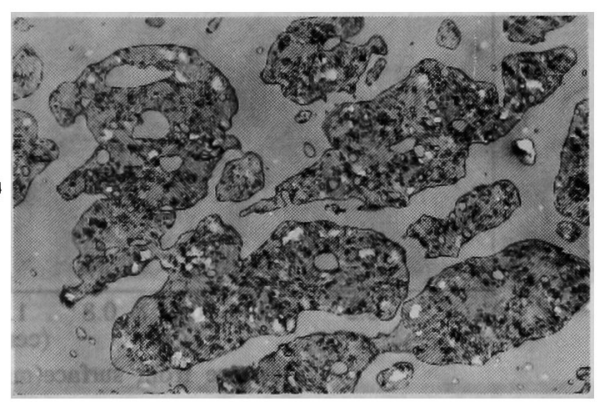

(b)

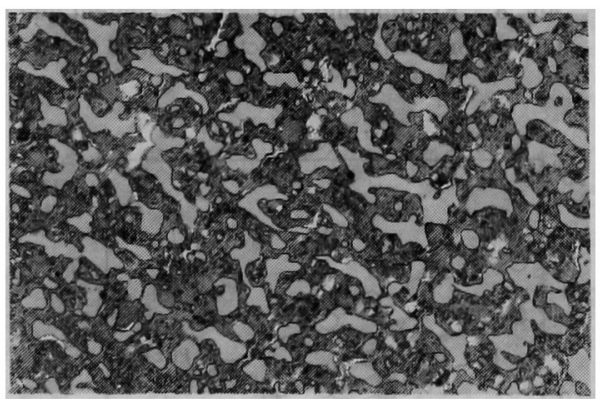

(c)

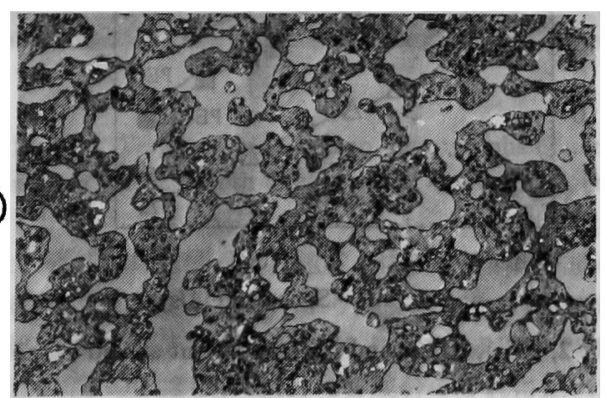

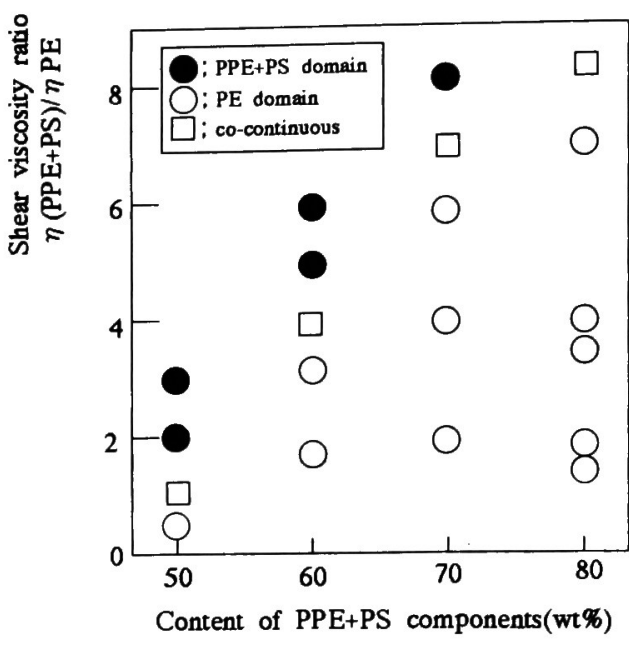

Fig. 12. Plot of phase morphology as a function of composition and viscosity ratio $\eta(\mathrm{PPE}+\mathrm{PS}) / \eta \mathrm{PE}$.

出成形における金型（キャビティサイズは，120 mm× $80 \mathrm{~mm} \times 2 \mathrm{~mm}$ 厚み) 内への樹脂充填時の CAE 解析を 行った. Flow 3D（CIMP 充填過程計算プログラム）を 用い, 2.2 で記述した射出成形条件を入力して,ずり速 度と樹脂温度の厚み方向の分布を試料 3 について計算し た. その結果を Fig. 13(a) に示す. 表面から 0.4 0.8 $\mathrm{mm}$ の領域でずり速度が大きくなり，それに伴う発熱に より樹脂温度も高くなっている様子がわかる。この計算 されたずり速度と温度に対応する各成分の溶融粘度を, 3.3.2 で測定したデータから計算し, 試料 3 に関して充 鲳固化時の $\eta(\mathrm{PPE}+\mathrm{PS}) / \eta \mathrm{PE}$ 値として整理した結果を Fig. 13(b) に示す. 計算された粘度比が成形品厚み方向 で変化し, 表面から $0.2 \sim 0.4 \mathrm{~mm}$ の領域で極めて大きく なっていることがわかる，なお，表面から約 $0.1 \mathrm{~mm}$ 程 度の領域はメルトフロントが大きなずり変形を伴うこと なく，樹脂温度から金型温度へ急冷されると考え，その 温度における低ずり速度下の粘度比を採用した。

この成形品内部での粘度比変化と, Fig. 12 で明らか になった粘度比, 組成と海島モルフォロジーの関係か ら, Fig. 7 に模式図で示した相反転を含む特殊な傾斜構 造の形成が理解できる.すすなお, 試料 3 では臨界粘度 比 $\eta(\mathrm{PPE}+\mathrm{PS}) / \eta \mathrm{PE}$ が約 4 であり, これより粘度比が 大きい側では PPE $(+\mathrm{PS})$ 相がドメイン, 小さい側では マトリックスを形成する. 実際の成形時のキャビティー

Fig. 11. Transmission electron micrographs of sample 4 at various different shear viscosity ratios of $\eta(\mathrm{PPE}+\mathrm{PS}) / \eta \mathrm{PE}$. Shear viscosity ratio is 0.8 (a), 3.0 (b) and 1.1 (c). 
PPE と PE のブレンド系の射出成形品中における相反転特殊傾斜構造の形成

(a)

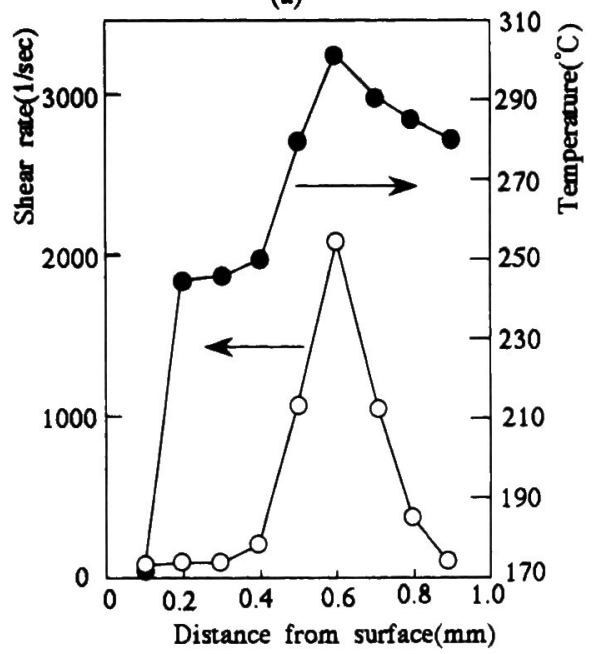

(b)

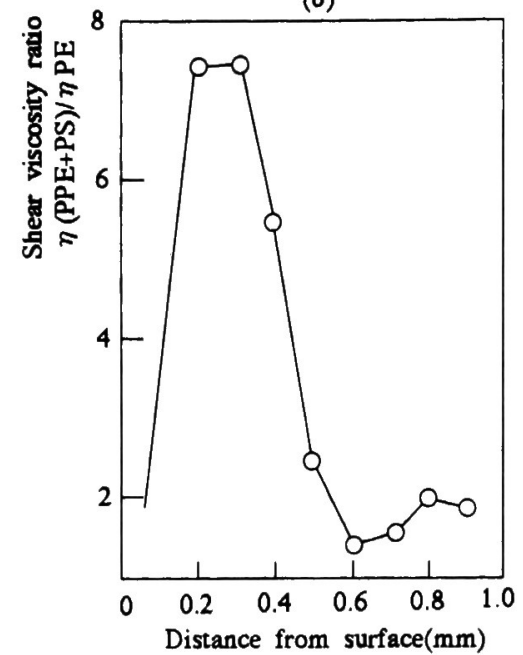

Fig. 13. Shear rate, temperature (a) and shear viscosity ratio (b) as a function of distance from the surface of injection molded sheet of sample 3 .

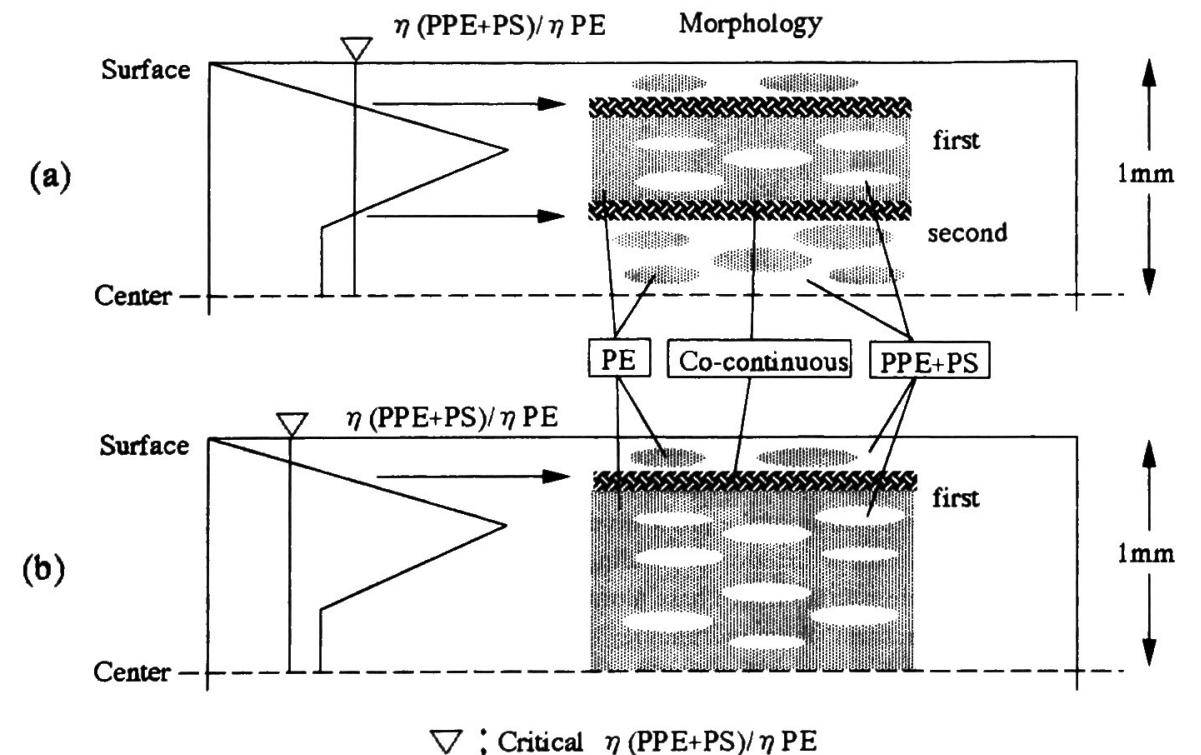

Fig. 14. Shematic representations of phase inversion mechanisms.

内での粘度比は, 表面からの距離が $0.2 \sim 0.45 \mathrm{~mm}$ の領 域で粘度比が 4 以上あり,この領域で PPE(+PS) がド メインになると予想され，実際に観察されたモルフォロ ジーと良く一致することがわかった，同様に，試料 4 で は臨界粘度比が約 1 であることから, 相反転が $0.2 \mathrm{~mm}$ の位置でのみ一度生じることがわかり, 観察したモル フォロジーと一致する。

以上の考え方に立脚すれば, PPE + PS 成分と PE 成
分の組成比を変化させた試料 1〜4，ならびに溶融粘度 比を変えた試料 5〜7の相反転した試料の観察結果をよ く説明することができる，その相反転特殊傾斜構造の形 成機構の概念図を Fig. 14 に示した. (a) は相反転が二 度生じる系であり，(b) は一度生じる系を例示した。

\section{4 材料性能}

相反転を示す特殊な傾斜構造が物性一及ぼす影響を調 べた．組成比が同一 $(P P E+P S / P E=80 / 20)$ で PPE+ 
PS成分がマトリックスである試料 5, PE 成分がマト リックスである試料 7 (いずれも相反転が起きていない 試料）および相反転が起きている試料 6 の成形品を用い て各種の物性を測定した。 また, 対照のため, PPE/PE (80/20), PS/PE (80/20) の試料についてあ評価した. 結果を Table 3 に示す. 相反転を含む特殊傾斜構造を有 する試料 6 は, PPE マトリックスまたはPE マトリック スよりなるブレンドに比較し，性能向上が顕著である. 特に注目すべきことは, 特殊傾斜構造を有する試料 6 は, 試料 5 と 7 の平均的特性が現れるのではなく, PPE マトリックスに特徵的な剛性や耐熱性能（熱変形温度, 線膨張係数，表面硬度）とPEマトリックスに特徵的な 靱性（衝撃強度）を併せ持つ材料であることである．通 常, 剛性と耐衝撃性は相反する特性であるが,これらの 特性を同時に満足する現象は, 学術的にも実用的にす極 めて意義深く, 今後新たな市場開拓の可能性を大いに秘 めていると思われる.

\section{4 結 論}

PPE とPEからなるブレンド系において，その射出成 形品中のモルフォロジーが厚み方向で相反転が 1 回ない しは 2 回起きる特殊な傾斜構造の形成が, ある粘度比之
組成の組み合わせの時に観察された. この形成機構を解 析した結果, 組成の变動が原因ではなく，射出成形充填 時のずり速度と樹脂温度に支配される両成分の溶融粘度 比が成形品の厚み方向で変化していることで説明するこ とができた. 特殊傾斜構造の形成により発現する物性 は, PPE マトリックスまたはPEマトリックスのブレン ドが示す特性の平均的な值に留まらず，両相の優れた物 性を共有する，従来にない優れた材料特性を示すことが 明らかになった。

\section{文献}

1) J. R. Campbell, S. Y. Hobbs, T. J. Shea, and V. H. Watkins, Polym. Eng. Sci., 30, 1056 (1990).

2) 佐野博成, 矢野一憲, 大井重和, 西田耕治, 成形加工, 6, 825 (1994).

3）佐野博成, 中川英昭, 丹下堅一，山森嘉則（三菱化学 (株)，三菱自動車(株)）特公平 2-311533.

4) 泰 功夫, 高分子, 40, 244 (1991).

5) B. D. Favis and J. P. Chalifoux, Polymer, 29, 1761 (1988).

6) G. I. Taylor, Proc. Roy. Soc. London, 138, 41 (1932).

7) S. Wu, Polym. Eng. Sci., 27, 335 (1987).

8) C. D. Han, J. Appl. Polym. Sci., 17, 1289 (1973).

9) J. L. White and B. L. Lee, Polym. Eng. Sci., 15, 481(1975).

Formation of "Gradient Phase Morphology" in Immisible Polymer Blends of Poly(2,6-dimethyl-1,4-phenylene) Ether and Polyethylene

Hironari SANo*1, Yoshihiro KURASAWA*1, and Kouji NishidA*1

${ }^{* 1}$ Yokkaichi Research Center, Mitsubishi Chemical Corporation (1, Toho-cho, Yokkaichi, Mie, 510 Japan)

${ }^{* 2}$ Technical Center Hiratsuka, Mitsubishi Engineering Plastics Corporation (5-6-2, Higashiyawata, Hiratsuka, Kanagawa, 254 Japan)

A novel morphology named "gradient phase morphology" is found in immisible polymer blends of amorphous polymer (PPE) and crystalline polymer (PE), in which phase inversion occurs along the thickness direction during the injection molding process. The mechanism of the phase inversion can be explained as follows. The viscosity ratio of the components changes along the thickness direction of molding product in processing because resin temperature and shear rate are different at various positions in a mold. Phase morphology is controlled by the viscosity ratio. It is found that polymer blends given such a "gradient phase morphology" show synergistic improvement of mechanical and thermal properties.

KEY WORDS Morphology / Poly(2,6-dimethyl-1,4-phenylene) Ether (PPE) and Polyethylene (PE) Blend /

Gradient Phase Morphology / Phase Inversion / Viscosity Ratio / Shear Rate / Mechanical Properties /

Thermal Properties /

(Received December 3, 1996: Accepted January 29, 1997)

[Kobunshi Ronbunshu, 54(4), 244-254 (1997)] 